\title{
Autoradiographic Study of the Localization and Evolution of Growth Zones in Bacterial Colonies
}

\author{
By J. REYROLLE* AND F. LETELLIER* \\ Laboratoire de Physiologie Bactérienne, Université de Caen, 14032 Caen Cedex, France
}

(Received 9 October 1978)

\begin{abstract}
Incorporation of $\left[{ }^{3} \mathrm{H}\right]$ leucine in the bacteria of 18 to $48 \mathrm{~h}$-old colonies of Pseudomonas aeruginosa, Pseudomonas putida, Bacillus thuringiensis, Staphylococcus aureus and Escherichia coli enabled the localization of bacterial multiplication sites by means of autoradiography of sagittal sections. In colonies where fast diameter expansion occurred, all the bacteria from the peripheral corona contributed to peripheral growth; in colonies where the expansion was slower, the growth rate of the bacteria in this region was heterogeneous. Besides this peripheral growth, a central region of bacterial multiplication was always found, but with variable localization and extension. In aerobic species, such as $P$. aeruginosa and $P$. putida, the central growth site was limited to the zone of oxygen penetration into the bacterial mass. However, in facultatively anaerobic species, bacterial multiplication depended on nutrient supply. For $48 \mathrm{~h}$-old colonies of $S$. aureus, a more complex localization of growth seemed to be affected simultaneously by nutrient penetration and accumulation of toxic substances.
\end{abstract}

\section{INTRODUCTION}

Although in nature bacteria multiply as colonies or related formations (flocs, slimes, clumps), much less study has been devoted to this form of growth than to dispersed growth in liquid medium. In particular, there is little information on the localization of proliferating cells within a colony of bacteria.

It is relatively easy to observe directly the genesis of microcolonies by means of an optical microscope (Bisset, 1938; Hoffman \& Franck, 1961; Brock, 1971), but this technique is no longer applicable when a certain stage of development has been reached. Classical histological techniques yield little information on the zones of proliferation since they only show morphological or staining differences. This is especially true for Mycobacterium tuberculosis colonies (Arloing \& Malartre, 1925; Kahn \& Nonidez, 1933) and some mature eubacterial colonies (Legroux \& Magrou, 1920; Spanedda, 1958).

Dimensional criteria have also been used to study growth in bacterial colonies. Thus, Pirt (1967), Cooper et al. (1968) and Palumbo et al. (1971) followed growth by measuring the increase in colony diameter, and occasionally thickness, and demonstrated the presence of a clearly localized peripheral growth zone. The bacteria responsible for the increase in thickness of the colony cannot, however, be located in this zone.

Recently, Wimpenny \& Lewis (1977) measured the oxygen consumption of young colonies and deduced that the depth of oxygen penetration varied according to the species and must therefore necessarily lead to different locations for internal colony growth.

We have devised a method for precisely locating the growth zones in a colony, based on

* Present address: Génétique Microbienne Fondamentale et Appliquée, Université de Caen, 14032 Caen Cedex, France. 
a technique of section autoradiography (Reyrolle \& Letellier, 1974), and have used it to study the distribution of growth zones in 18 to $48 \mathrm{~h}$-old colonies of five bacterial species.

\section{METHODS}

Bacteria and growth. The following micro-organisms were used: Staphylococcus aureus (Institut Pasteur no. 52156), Bacillus thuringiensis var. Berliner (for which we thank P. Boutibonnes, see Boutibonnes, 1975), Pseudomonas putida, Escherichia coli and Pseudomonas aeruginosa (from our laboratory collection). The organisms were cultured on Ryter \& Kellenberger's (1958) S synthetic medium, supplemented with Difco yeast extract ( $\left.3 \mathrm{mg} \mathrm{ml}^{-1}\right)$, except for $P$. putida which was grown on PB semi-synthetic medium containing: Difco peptone, $0.2 \mathrm{~g}$; sodium benzoate, $0.5 \mathrm{~g}$; mineral solution (Kauffmann, 1967), $5 \mathrm{ml}$; agar, $1.5 \mathrm{~g}$; and water, $100 \mathrm{ml}$; adjusted to $\mathrm{pH} 7.2$ with $\mathrm{NaOH}$.

Each strain was grown for $16 \mathrm{~h}$ at $37^{\circ} \mathrm{C}\left(27^{\circ} \mathrm{C}\right.$ for $P$. putida and $B$. thuringiensis $)$ in liquid medium and then seeded with a microdrop from a straight metallic thread on fragments of Millipore membrane (HAWP 047) placed on solid medium (S or PB). At different times, a membrane bearing a colony was transferred, under sterile conditions, to a medium of the same composition and depth containing $\left[{ }^{3} \mathrm{H}\right]$ leucine $\left(5 \mu \mathrm{Ci} \mathrm{ml}^{-1}\right.$, specific activity $250 \mathrm{mCi} \mathrm{mmol}^{-1}$; The Radiochemical Centre, Amersham) for 3 to $6 \mathrm{~h}$. For all media, the depth of agar was $3.2 \mathrm{~mm}$.

Autoradiography. After incubation, the filters bearing the colonies were immersed for $1 \mathrm{~h}$ in formaldehyde/ $70 \%$ (v/v) ethanol/glacial acetic acid (5:15:1, by vol.). Membranes were cut with a razor blade as near to the edge of each colony as possible, and the membrane pieces with attached colonies were washed for $2 \mathrm{~h}$ before dehydration and embedding in Spurr's epoxy resin. Semi-fine sections were cut with a glass knife on a Porter Blum Sorvall no. 2 microtome and collected on gelatinized slides (Ilford). The slides were dipped in $\mathrm{L} 4$ emulsion (Ilford). After 7 to $8 \mathrm{~d}$ exposure at $4{ }^{\circ} \mathrm{C}$ slides were developed with D19b developer (Kodak). The sections were exclusively saggital. Where indicated, they were stained with toluidine blue prior to observation. For each experiment at least five colonies were studied.

\section{RESULTS AND DISCUSSION}

The colonies studied were 18 to $48 \mathrm{~h}$-old, during which time the diameter of all colonies increased linearly (S. aureus, $0.062 \mathrm{~mm} \mathrm{~h}^{-1} ;$ E. coli, $0.066 \mathrm{~mm} \mathrm{~h}^{-1} ; P$. putida, $0.093 \mathrm{~mm} \mathrm{~h}^{-1}$; $P$. aeruginosa, $0.097 \mathrm{~mm} \mathrm{~h}^{-1} ; B$. thuringiensis, $0.110 \mathrm{~mm} \mathrm{~h}^{-1}$ ). According to Pirt (1967) and Palumbo et al. (1971), this growth period corresponds to an equilibrium phase that is characteristic of a bacterial colony.

$\left[{ }^{3} \mathrm{H}\right]$ Leucine was chosen as the labelled precursor since it is almost entirely incorporated into protein (Caro, 1961), thus indicating the sites of bacterial proliferation. In nonproliferating bacteria the incorporation of this amino acid following protein turnover was negligible compared with incorporation in proliferating organisms.

\section{Peripheral growth}

Autoradiographs prepared from those colonies which had relatively faster diameter increases, e.g. $P$. aeruginosa (Figs $1 a, 1 d, 14$ ), $P$. putida (Figs $2 a, 2 d, 11$ ) and $B$. thuringiensis (Figs $3 a, 3 d, 18$ ), showed homogeneous labelling of the section extremities. On the other hand, sections of colonies which expanded more slowly, e.g. S. aureus (Figs $5 a, 5 d, 6,8$ ) and $E$. coli (Figs $4 a, 4 d, 16$ ), were more intensely labelled at their bases in contact with the growth medium. The regular labelling of the peripheral corona characteristic of colonies with fast diameter growth indicates that all the bacteria of this region are under identical growth conditions. Oxygen therefore diffuses easily through a relatively thin bacterial mass and nutrient supply is satisfactory; this is probably facilitated by the cells' own mobility. Conversely, in colonies with slow diameter growth, a heterogeneity rapidly appears in the growth rate of the bacteria in the peripheral zone. 
(a)

1. Pseudomonas aeruginosa

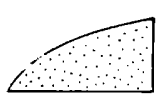

2. Pseudomonas putida

3. Bacillus thuringiensis

4. Escherichia coli

5. Staphylococcus aureus (b)
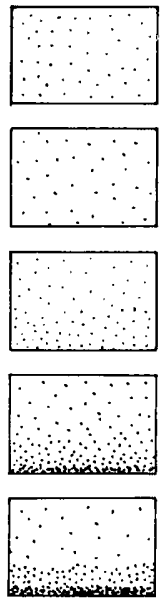

(c)
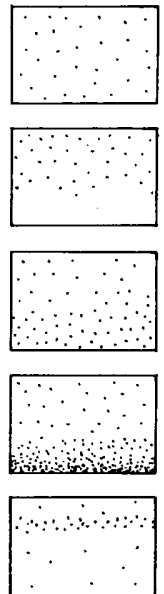

(d)
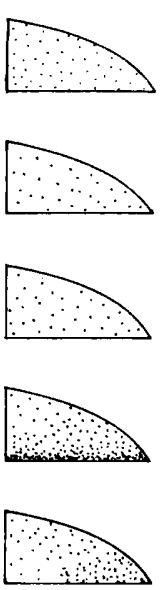

Figs 1 to 5 . Diagrams showing the label distribution in sagittal sections of colonies: $(a, d)$ peripheral zone; $(b, c)$ central zone.

Fig. 1. Pseudomonas aeruginosa on $\mathrm{S}$ medium. Colonies were grown for $24 \mathrm{~h}(a, b)$ or $34 \mathrm{~h}(c, d)$ followed by labelling for $4 \mathrm{~h}$.

Fig. 2. Pseudomonas putida on PB medium. Colonies were grown for $20 \mathrm{~h}$ followed by labelling for $3 \mathrm{~h}(a, b)$ or grown for $30 \mathrm{~h}$ followed by labelling for $4 \mathrm{~h}(c, d)$.

Fig. 3. Bacillus thuringiensis on S medium. Colonies were grown for $18 \mathrm{~h}(a, b)$ or $32 \mathrm{~h}(c, d)$ followed by labelling for $4 \mathrm{~h}$.

Fig. 4. Escherichia coli on S medium. Colonies were grown for $24 \mathrm{~h}(a, b)$ or $36 \mathrm{~h}(c, d)$ followed by labelling for $4 \mathrm{~h}$.

Fig. 5. Staphylococcus aureus on $\mathrm{S}$ medium. Colonies were grown for $24 \mathrm{~h}$ followed by labelling for $3 \mathrm{~h}(a, b)$ or grown for $48 \mathrm{~h}$ followed by labelling for $6 \mathrm{~h}(c, d)$.

\section{Central colony growth}

The distribution of label in the central zones of the colonies studied differed according to the species and the age of the colony. In young colonies $(24 \mathrm{~h})$ of $P$. aeruginosa (Fig. $1 b)$ and $P$. putida (Figs $2 b, 10$ ), the whole depth of the colony was labelled with the same intensity. Thus all the bacteria, whatever their position, must benefit from a nutrient and oxygen (for aerobic strains) supply enabling them to multiply at equivalent rates. In older $(34$ h) $P$. aeruginosa colonies, no marked variation of label was seen between the base and the summit (Figs $1 c, 13)$. However, in older $(30 \mathrm{~h}) P$. putida colonies, the label was limited to the top two-thirds of the colony (Figs $2 c, 12$ ). In these strictly aerobic species, the diffusion of oxygen probably plays a crucial role, and in a thicker colony only those organisms located in an upper layer, through which oxygen can penetrate, will multiply enabling the colony to increase further in thickness.

For the facultatively anaerobic species studied, the growth zone within the colony was a basal zone whose thickness varied according to the species. For $E$. coli (Figs $4 b, 4 c, 15$ ) and $S$. aureus (Figs $5 b, 7$ ) this zone was quite discrete, whereas for $B$. thuringiensis (Figs $3 b$, $3 c, 17)$ labelling decreased progressively towards the summit.

Nutrient supply appears to play a key role in the localization of growth zones for facultative anaerobes. The bacteria located at the base of the colonies can multiply faster than those near the surface, despite the opportunity in the latter of an aerobic metabolism with a more favourable yield. Diffusion of substances throughout the colony is probably a function of both the magnitude of the interbacterial volume and the nature of the interbacterial substance. This might explain some differences observed, e.g. in $B$. thuringiensis the basal growth zone embraces a thicker layer than in $S$. aureus or $E$. coli since diffusion of 

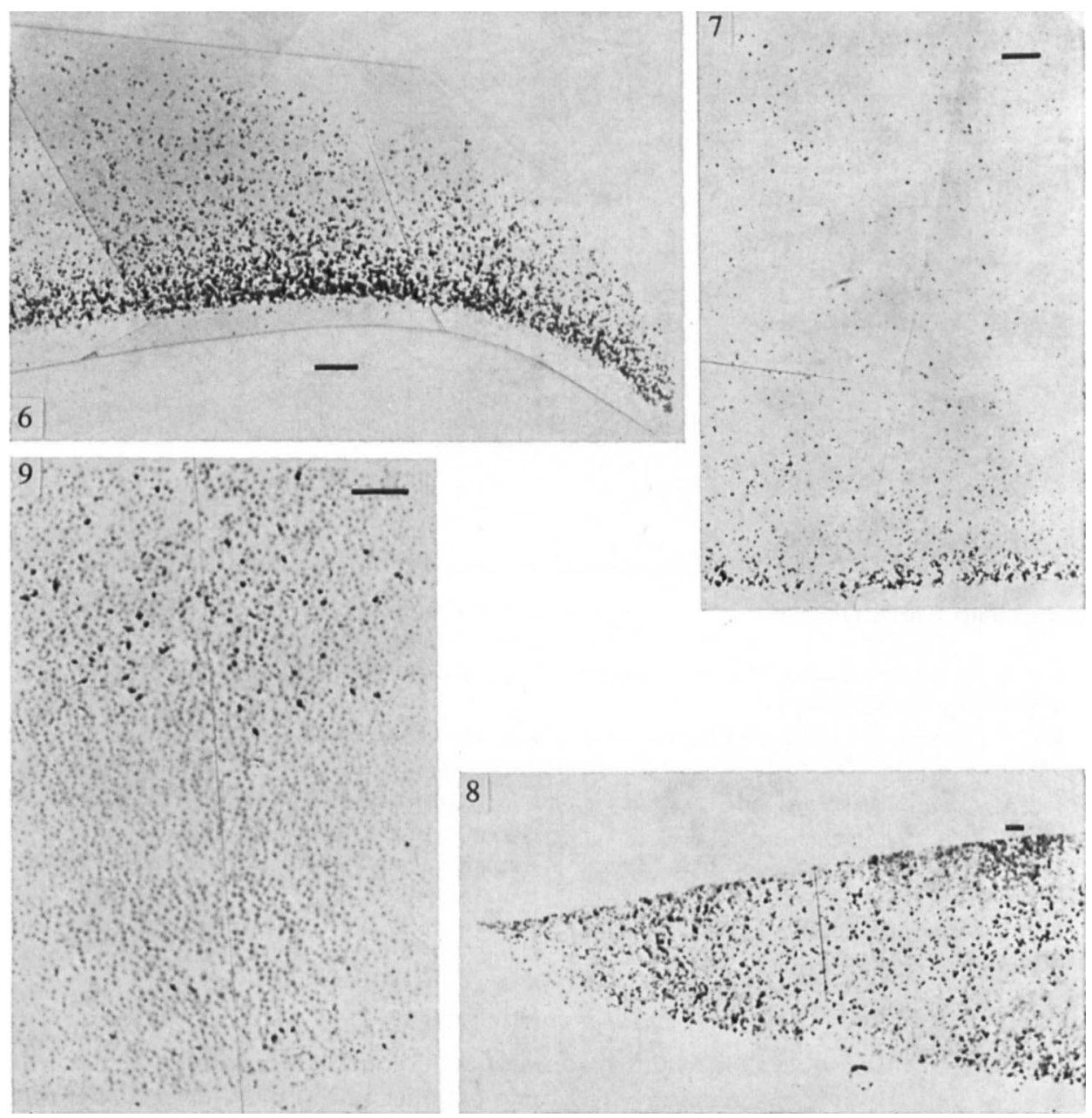

Sagittal sections, unstained (Figs 6 and 7) or stained with toluidine blue (Figs 8 and 9); bar markers represent $10 \mu \mathrm{m}$.

Figs 6 to 9. Staphylococcus aureus on S medium. Colonies were grown for $24 \mathrm{~h}$ followed by labelling for $3 \mathrm{~h}$ (Figs 6 and 7) or grown for $48 \mathrm{~h}$ followed by labelling for $6 \mathrm{~h}$ (Figs 8 and 9): Figs 6 and 8 show peripheral zones of colonies, Figs 7 and 9 show central zones.

nutrient substances occurs more easily between the cells. Apart from the basal zones, a diffuse and regular label was also seen, probably due to slow cell proliferation as well as to protein turnover.

In $S$. aureus, as the colony aged, the weak labelling (duration $6 \mathrm{~h}$ ) was located mainly within a fairly well-defined band below the surface (Figs $5 c$, 9). A possible explanation for this is that growth occurs in a zone where the opposing effects of two gradients balance, one consisting of toxic substances tending to accumulate at the base of the colony, and the other of nutrient substances migrating from the base (higher concentration) towards the summit. Inhibition of bacterial multiplication at the base of the colony could also result from the spherical shape of the organisms leaving only a relatively small interbacterial space through which oxygen may diffuse (c.f. Wimpenny \& Lewis, 1977). 

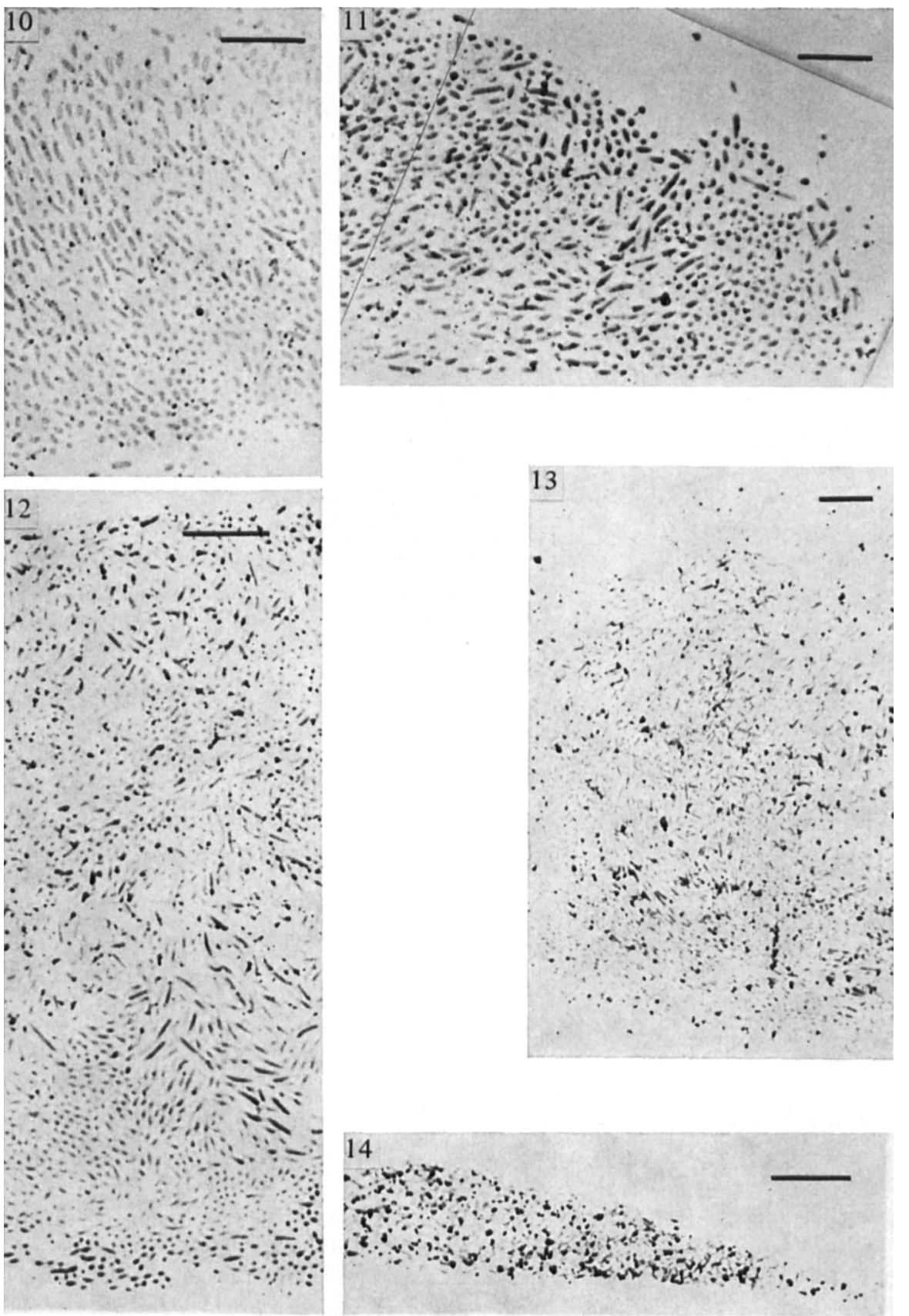

Sagittal sections stained with toluidine blue; bar markers represent $10 \mu \mathrm{m}$.

Figs 10 to 12. Pseudomonas putida on PB medium. Colonies were grown for $20 \mathrm{~h}$ followed by labelling for $3 \mathrm{~h}$ (Fig. 10) or grown for $30 \mathrm{~h}$ followed by labelling for $4 \mathrm{~h}$ (Figs 11 and 12): Figs 10 and 12 show central zones of colonies and Fig. 11 shows a peripheral zone.

Figs 13 and 14. Pseudomonas aeruginosa on S medium. Colonies were grown for $34 \mathrm{~h}$ (Fig. 13) or $24 \mathrm{~h}$ (Fig. 14) followed by labelling for $4 \mathrm{~h}$ : Fig. 13 shows a central zone and Fig. 14 shows a peripheral zone. 

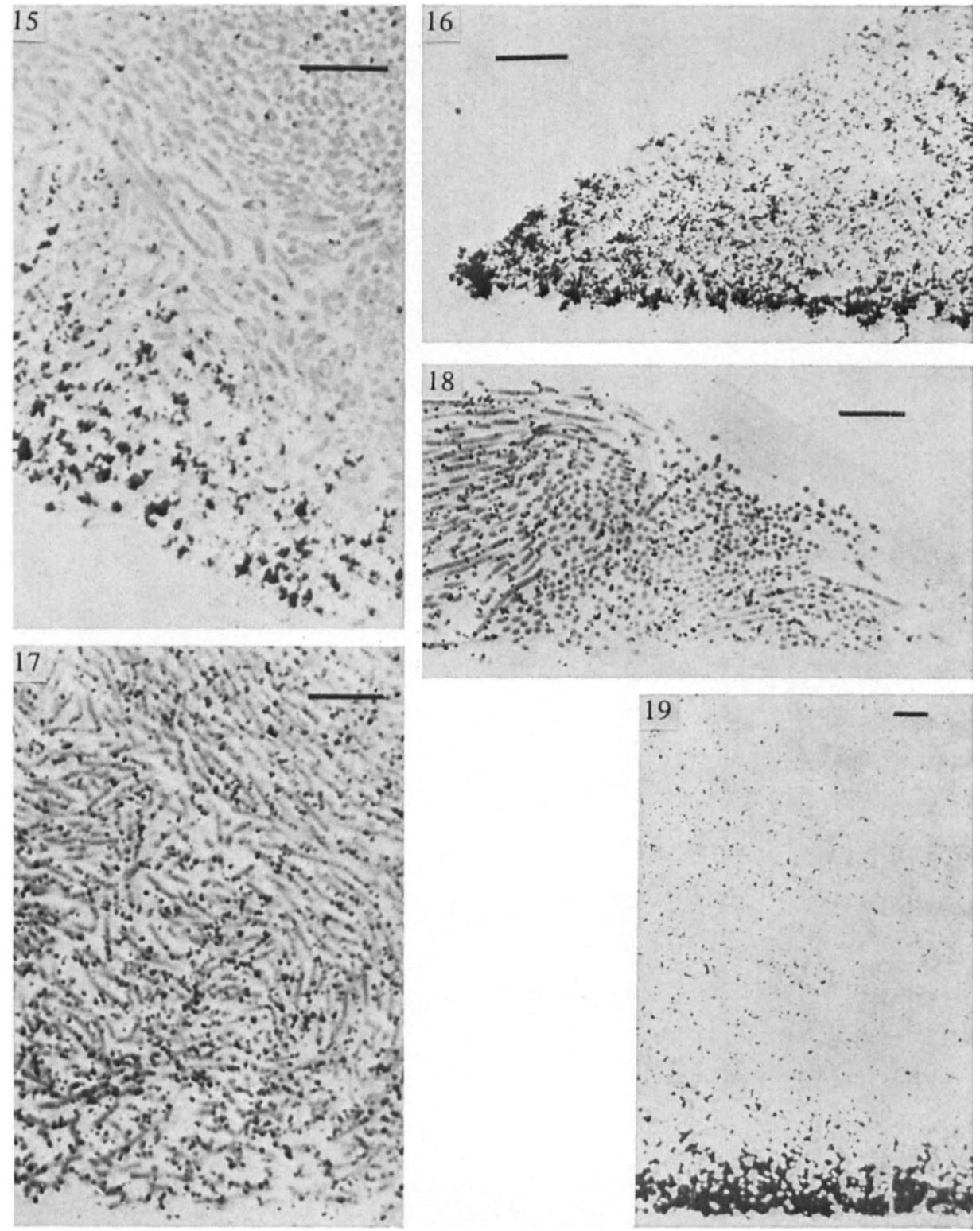

Sagittal sections, stained with toluidine blue (Figs 15 to 18) or unstained (Fig. 19); bar markers represent $10 \mu \mathrm{m}$.

Figs 15 and 16. Escherichia coli on S medium. Colonies were grown for $36 \mathrm{~h}$ (Fig. 15) or $24 \mathrm{~h}$ (Fig. 16) followed by labelling for $4 \mathrm{~h}$; Fig. 15 shows a central zone (basal) of a colony and Fig. 16 shows a peripheral zone.

Figs 17 and 18. Bacillus thuringiensis on $\mathrm{S}$ medium. Colonies were grown for $32 \mathrm{~h}$ followed by labelling for $4 \mathrm{~h}$ : Fig. 17 shows a central zone (basal) and Fig. 18 shows a peripheral zone.

Fig. 19. Staphylococcus aureus on $\mathrm{S}$ medium. Central zone of a colony grown for $24 \mathrm{~h}$ followed by labelling for $6 \mathrm{~h}$. 


\section{Influence of transfer on localization of the growth zones}

The technique used involved transfer to fresh medium containing $\left[{ }^{3} \mathrm{H}\right] l$ leucine for 3 to $6 \mathrm{~h}$. Under these experimental conditions, and for colonies 18 to $48 \mathrm{~h}$-old, it is unlikely that the transfer caused any modification in the zones of growth localization for the following reasons:

1. Colonies were cultivated on a membrane for 18 or $36 \mathrm{~h}$. For the next $12 \mathrm{~h}$, groups of colonies on filters were transferred every $3 \mathrm{~h}$ to medium of identical composition until they were 30 or $48 \mathrm{~h}$-old respectively. During this time, the increase in colony diameter occurred at the same rate as for colonies that had not been transferred. The measurement of diameter increase is a good estimate of colony growth (Pirt, 1975). Therefore, since no significant variation was discernible after several successive transfers had been made, it is probable that a single transfer would have no observable effect on these experiments.

2. Colonies of the same species transferred at different stages of growth did not always give the same result, as might have been expected if the normal conditions of growth were disturbed. Thus, 20 h-old $P$. putida colonies were labelled throughout the whole depth of the central region (Fig. 10), but in $30 \mathrm{~h}$-old colonies the label was limited to the top twothirds of the colony (Fig. 12).

3. The length of the incubation period ( 3 to $6 \mathrm{~h}$ ) in the fresh environment did not modify the distribution of the labelling zones, only their intensity. Thus, when $24 \mathrm{~h}$-old $S$. aureus colonies were transferred to fresh medium with [ $\left.{ }^{3} \mathrm{H}\right]$ leucine and incubated for $3 \mathrm{~h}$ (Fig. 7) or $6 \mathrm{~h}$ (Fig. 19), the labelling zones were identical and only the labelling intensity was increased.

The study of bacterial multiplication sites within a colony, by means of autoradiography, has provided information concerning their localization and evolution. In the peripheral zone, the main factor seems to be bacterial mobility. Colonies of the most mobile organisms show a faster increase in diameter and are characterized by a homogeneous growth zone. A central growth zone is observed in addition to the peripheral zone. The position of this central zone seems to depend mainly on factors such as oxygen requirement for growth and the composition and extent of the interbacterial space, which affects the diffusion of nutrient and toxic substances and of oxygen. Thus, when studying the complex structure that constitutes a bacterial colony, the crucial part played in its growth and evolution by this 'inner medium' must be taken into account. It should be possible to extend the application of this technique to bacterial clusters that exist in various forms either in nature or in certain technical procedures (e.g. microbial films in fermenters and trickling filters).

\section{REFERENCES}

Arloing, F. \& Malartre, E. (1925). Aspects des coupes de culture de bacilles tuberculeux sur pomme de terre. Comptes rendus des séances de la Société de Biologie et de ses filiales 93, 225-227.

BisSET, K. (1938). The structure of 'Rough' and 'Smooth' colonies. Journal of Pathology and Bacteriology 47, 223-229.

Boutibonnes, P. (1975). Sensibilité de souches de Bacillus thuringiensis (Berliner) sensibles et résistantes à l'aflatoxine $\mathrm{B}_{1}$, à quelques mycotoxines. Comptes rendus hebdomadaire des séances de l'Académie des sciences 280D, 1031-1034.

Brock, D. (1971). Microbial growth in nature. Bacteriological Reviews 35, 39-58.
CARo, L. G. (1961). Localisation of macromolecules in Escherichia coli (I). Journal of Biophysical and Biochemical Cytology 9, 539-565.

Cooper, A. L., Dean, A. C. R. \& Hinshelwood, C. (1968). Factors affecting the growth of bacterial colonies on agar plates. Proceedings of the Royal Society B 171, 175-199.

Hoffman, H. \& Franck, M. E. (1961). Form and internal structure of cellular aggregations in early Escherichia coli microcultures. Journal of General Microbiology 25, 353-364.

KaHN, M. C. \& NonideZ, J. F. (1933). Non-acid fast rods and granules in vertical sections of Mycobacterium tuberculosis colonies. Proceedings 
of the Society for Experimental Biology and Medicine 30, 577-582.

KaUfFman, J. (1967). Sur la vitesse de croissance d'Azotobacter chroococcum en fonction de la source carbonée. Comptes rendus des séances de la Société de Biologie et de ses filiales 161, 2465-2467.

Legroux, R. \& MaGrou, J. (1920). Etat organisé des colonies bactériennes. Annales de l'Institut Pasteur 34, 417-433.

Palumbo, S. A., Johnson, M. G., Rieck, V. T. \& WitTER, L. D. (1971). Growth measurements on surface colonies of bacteria. Journal of General Microbiology 66, 137-143.

PIRT, S. J. (1967). A kinetic study of the mode of growth of surface colonies of bacteria and fungi. Journal of General Microbiology 47, 181-197.
PIRT, S. J. (1975). Principles of Microbe and Cell Cultivation. Oxford: Blackwell Scientific Publications.

Reyrolle, J. \& Letellier, F. (1974). Study of growth of bacterial colonies by autoradiography. International Research Communications System - Medical Science 2, 1483.

Ryter, A. \& Kellenberger, E. (1958). Etude au microscope électronique de plasmas contenant de l'acide désoxyribonucléique. Zeitschrift für Naturforschung 13b, 597-605.

Spanedda, A. (1958). Cito-architettonica di colonie bacillari. Rivista dell'Istituto sieroterapico italiano 1, 37-46.

Wimpenny, J. W. T. \& LeWIS, M. W. A. (1977). The growth and respiration of bacterial colonies. Journal of General Microbiology 103, 9-18. 